\title{
Physical and Chemical Attributes of Yellow Oxisol With the Application of Cassava Wastewater After Intensive Mechanical Preparation
}

\author{
Iara Oliveira Fernandes ${ }^{1}$, José Fernandes de Melo Filho ${ }^{1}$, Karolina Oliveira Rocha Montenegro ${ }^{1}$, \\ Ésio de Castro Paes ${ }^{2}$, Sergio Ricardo Matos Almeida ${ }^{1}$, João Albany Costa ${ }^{1} \&$ Franceli da Silva ${ }^{1}$ \\ ${ }^{1}$ Federal University of the Recôncavo, Bahia, Brazil \\ ${ }^{2}$ Federal University of Viçosa, Minas Gerais, Brazil \\ Correspondence: Iara Oliveira Fernandes, Federal University of the Recôncavo of Bahia, Cruz das Almas, Bahia, \\ Brazil. E-mail: iara158@gmail.com
}

\author{
Received: February 1, $2019 \quad$ Accepted: March 3, $2019 \quad$ Online Published: May 15, 2019 \\ doi:10.5539/jas.v11n6p113 URL: https://doi.org/10.5539/jas.v11n6p113
}

\begin{abstract}
The objective of this work was to evaluate the effect of the application of cassava wastewater in the production of dry mass of the spontaneous vegetation and in the physical and chemical attributes of a Dystrocohesive Yellow Oxisol submitted to intensive mechanical preparation in the Bahia Recôncavo. The experimental design was a $2 \times 2$ factorial scheme in 4 randomized blocks, the bands consisting of the intensity of the mechanical preparation of plowing followed by sorting: T0: without preparation; T1: 4 preparations; T2: 8 preparations and T3: 12 preparations; the first factor is the presence of cassava wastewater: M-with cassava wastewater; W-only water and the second factor presence or not of vegetation: $\mathrm{CV}$-with vegetation and $\mathrm{SV}$-without vegetation. The results of the analysis of soil attributes in the depth of $0.0-0.15 \mathrm{~m}$ showed that the $\mathrm{pH}$, saturation by base (V\%), macroporosity (Ma) and total porosity (TP) decreased linearly with the increase of the intensity of the mechanical preparation, however soil density (SD) increased. The application of cassava wastewater reduced the resistance to penetration (PR), $\mathrm{pH}$ and $\mathrm{Ca}^{2+}$ and $\mathrm{V} \%$ of the soil and increased the dry mass productivity of the spontaneous vegetation and the contents of phosphor.
\end{abstract}

Keywords: conventional preparation, organic waste, soil recovery

\section{Introduction}

Agricultural and livestock systems, based on intensive mechanical preparation, excessive use of fertilizers, irrigation with low quality water, application of pesticides and animal trampling, together with disorderly urban development and mineral exploration are the main anthropogenic causes of soil degradation in Brazil (Blanco \& Lal, 2010).

The conventional system of agricultural production is characterized by the intensive mechanical preparation of the soil, which results in the reduction of the average size and the stability of the aggregates in the mobilized layer; reduction of organic matter content; reduction of porosity; increased soil density and resistance to root penetration; decreased water infiltration; increased runoff and erosion (Assis \& Lanças, 2010; Lourente et al., 2011; Hickmann, Costa, Schaefer, \& Fernandes, 2011; Vezzani \& Mielniczuk, 2011; Portella, Guimarães, Feller, Fonseca, \& Tavares Filho, 2012).

Other consequences of conventional agricultural production systems are related to soil chemical attributes, as they promote changes in cation exchange capacity, $\mathrm{pH}$ and ion dynamics (Falleiro et al., 2003). In this context, soils impacted by intensive use, with the passage of time tends to lose nutrient contents by leaching (Bertol, Schick, Massariol, Reis, \& Dilly, 2000; Costa, Albuquerque, Bayer, Fontoura, \& Wobeto, 2003; Gatiboni et al., 2003; Kibblewhit, Ritz, \& Swift, 2007).

Recovering degraded soils is not an easy process. In this sense, few studies address methods for recovering soil sustainably via use of organic waste (Medina et al., 2015), such as organic sludge, residual corn biomass and shredded cotton residues, to increase recalcitrant organic matter, improve porosity and soil aggregate stability (Tejada \& Gonzales, 2003; Lynch, Voroney, \& Warman, 2006; Chiochetta et al., 2015). 
In addition to these residual biomasses, studies have shown that liquid organic biomass, such as vinasse from the processing of sugarcane, and cassava wastewater (manipueira) promote the improvement of the chemical and physical attributes of the soil (Mélo, Ferreira, Ruiz, Matos, \& Oliveira, 2005; Da Silva Júnior et al., 2012; Da Silva, Bono, \& Pereira, 2014).

The cassava wastewater is a liquid residue of milky aspect and light-yellow color, obtained from the pressing of cassava roots (Manihot esculenta Crantz) for the production of starch or flour. Such residue presents great potentialof use as agricultural fertilizer (Ponte, 2006; Magalhães et al., 2014), because it presents high organic load and high concentration of nutrients, mainly $\mathrm{K}^{+}, \mathrm{Mg}^{2+}, \mathrm{N}$ and P (Cardoso et al., 2009; Duarte et al., 2013).

Neves et al. (2014), a study of the residue of a flour mill industry in the region of Vitória da Conquista in Bahia, found a composition of $201.5 \mathrm{mg} \mathrm{L}^{-1}$ de phosphorus, 4.044,0 mg L-1 of potassium, $29.5 \mathrm{mg} \mathrm{L}^{-1}$ of calcium, 288.4 $\mathrm{mg} \mathrm{L}^{-1}$ of magnesium and $22.7 \mathrm{mg} \mathrm{L}^{-1}$ sulfur. Ferreira, Botelho, Cardoso, and Poltronieri (2001), and Duarte et al. (2013) also found a similar composition.

Due to this rich composition, some studies have demonstrated positive effects of cassava wastewater in the productivity of crops such as lettuce, corn, banana and tomato (Nasu, Pires, Fermentini, \& Furlanetto, 2010; Santos et al., 2010; Da Silva Júnior et al., 2012; Ferreira, Ferreira, Araujo, \& Oliveira, 2012), as well as on soil attributes, such as increase in $\mathrm{P}, \mathrm{K}^{+}, \mathrm{Ca}^{2+}, \mathrm{Mg}^{2+}, \mathrm{Na}^{+}$exchangeable, CEC, $\mathrm{V} \%$ and flocculation levels. It also promoted positive effects on physical attributes: soil particle density and porosity, as well as the increase in $\mathrm{pH}$, when used in small doses (Mélo et al., 2005; Da Silva Júnior et al., 2012; Duarte et al., 2013).

Despite its advantages, the cassava wastewater is still one of the many industrial wastes improperly disposed of in the environment. The flour houses generate significant quantities of cassava wastewater, reaching a minimum volume of 250 liters per ton of processed root (Ferreira et al., 2001). As a result of its chemical composition, organic load and difficult disposal management, if it is incorrectly discarded the cassava wastewater can cause serious damages to the environment and to the well being of the population, polluting the soil, air, surface water, underground and causing problems of bad odors (De Araújo et al., 2014; Magalhães et al., 2014; Souza, Oliveira, Cavagis, \& Botero, 2014).

Considering the hypothesis that the use of cassava wastewater in degraded areas can be an alternative both for the improvement of physical and chemical attributes of these areas, and for the adequate final disposal of this residue. The objective of this work was to evaluate the effect of the application of cassava wastewater in the production of dry mass of the spontaneous vegetation and the physical and chemical attributes of a Dystrocohesive Yellow Oxisol submitted to intensive mechanical preparation in the Bahia Recôncavo, Brazil.

\section{Material and Methods}

\subsection{Characterization of the Area}

The study was conducted in the area of Experimental Farm I, located at the Federal University of Recôncavo of Bahia (UFRB), Cruz das Almas campus, in the RecôncavoBaiano region, Brazil, located at coordinates: $12^{\circ} 39^{\prime} 22.9^{\prime \prime} \mathrm{S}$ and $39^{\circ} 04^{\prime} 59.36^{\prime \prime} \mathrm{W}$, at an altitude of $212 \mathrm{~m}$. The soil of the experiment area was classified as a DystrocohesiveYellow Oxisol.

The local climate is characterized as warm and humid tropical with dry season in the summer, type as according to the classification of Köpeen with average annual rainfall of $1,131.2 \mathrm{~mm}$, average annual temperature of 23.9 ${ }^{\circ} \mathrm{C}$ and relative humidity of $81 \%$ (Embrapa, 2016).

In a period of 90 days, from the emergency to the collection of spontaneous vegetation, the Embrapa Cassava and Fruit Meteorological Station registered a minimum temperature of $18.09{ }^{\circ} \mathrm{C}$, average of $22.10{ }^{\circ} \mathrm{C}$ and maximum of $26.70{ }^{\circ} \mathrm{C}$. The relative humidity was $85.03 \%$ and mean rainfall was $3.5 \mathrm{~mm}$. The precipitation recorded during 20 days after the application of cassava wastewater was above average and is shown in Figure 1. 


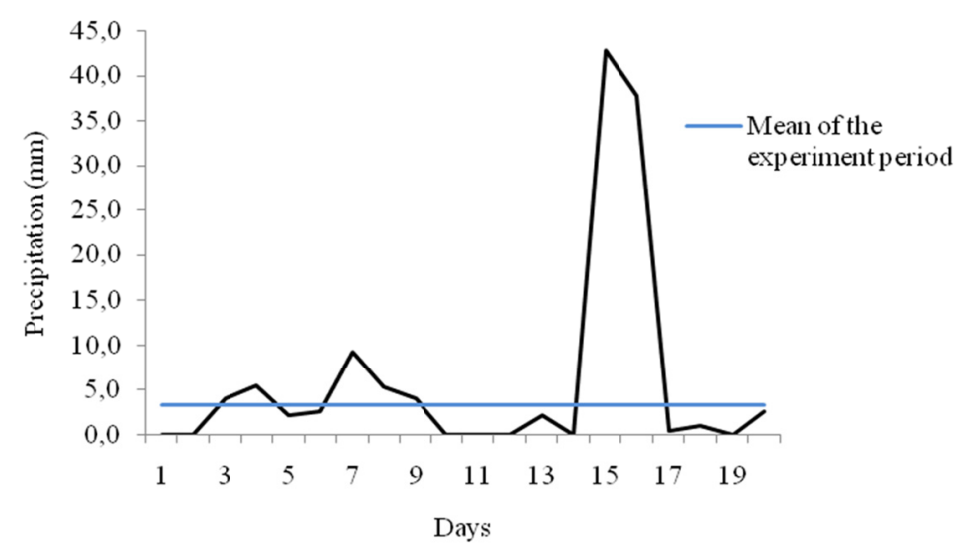

Figure 1. Precipitation in the 20 days after the application of cassava wastewater

\subsection{Experimental Design}

In an area under fallow for 5 years, with predominant vegetation of the species BraquiariadecumbensStapf. and soil classified as DystrocohesiveYellow Oxisol, four bands of $12 \times 6 \mathrm{~m}$ and $72 \mathrm{~m}^{2}$ were established, which were submitted to a monthly sequence of mechanical plowing preparation followed by harrowing at a depth of $0.3 \mathrm{~m}$ during the period of 12 months. During the study period mechanical scraping was performed every 3 months in all the bands. The tests were performed when the soil was at its friability point.

The experiment was delineated according to a $2 \times 2$ factorial scheme in 4 randomized blocks with five replicates, totaling 80 experimental plots of $3 \mathrm{~m}^{2}$ each, with the bands composed by the intensity of the mechanical preparation: T0: without mechanical preparation; T1: 4 mechanical preparations; T2: 8 mechanical preparations and T3: 12 mechanical preparations, and the factorial scheme by the presence or absence of cassava wastewater: $\mathrm{M}$-with cassava wastewater; $\mathrm{W}$-water only, associated with the presence or absence of spontaneous vegetation: $\mathrm{CV}$-with vegetation and SV-without vegetation. The whole area was cleared before the application of cassava wastewater and the plots maintained without vegetation were weeded biweekly.

\subsection{Cassava Wastewater Application}

In order to obtain the dosage of cassava wastewater to be applied, a mean of the dosages of the same one that reached the best results in the soil was sought by means of theoretical reference. Based on these studies (Cardoso et al., 2009; Cabral, Freitas, Bertonha, \& Muniz, 2010; Da Silva Júnior et al., 2012; Duarte et al., 2013; Magalhães et al., 2014; Dantas et al., 2015; Bezerra et al., 2017) the average dose of cassava wastewater of 90 $\mathrm{m}^{3} \mathrm{ha}^{-1}$, corresponding a $9 \mathrm{~L} \mathrm{~m}^{-2}$ was adopted.

The cassava wastewater has in its composition a glycoside called linamarin, which is hydrolyzed to hydrocyanic acid, whose presence causes serious damage to the environment when it is discarded in natura form, without previous rest (De Araújo et al., 2014; Souza et al., 2014). This characteristic indicated the need to store the cassava wastewater used in the study for 20 days, sufficient time for release of the hydrocyanic acid, as indicated by Ferreira et al. (2001).

The predicted dosage of $9 \mathrm{~L} \mathrm{~m}^{-2}$ was diluted in 24 liters of water, resulting in a solution of $33 \mathrm{~L} \mathrm{~m}^{-2}$ applied. The purpose of this procedure was to moisten the soil depth corresponding to a water depth of $0.15 \mathrm{~m}$. In the plots without cassava wastewater only water was applied in the same dosage of $33 \mathrm{~L} \mathrm{~m}^{-2}$ of water, in order to isolate the effect of the water present in the cassava wastewater in the results of the experiment.

The cassava wastewater was collected in a flour house in the Rural Area of the municipality of Cruz das Almas-BA, $7 \mathrm{~km}$ from UFRB. Its composition and $\mathrm{pH}$ were evaluated at the Center for Agricultural and Environmental Technology of Paracatu in Minas Gerais. The same analysis revealed that the applied cassava wastewater had values well below the reading accuracy of the equipment used in relation to: organic matter content lower than $31 \mathrm{~g} \mathrm{~L}^{-1}$, oxidizable organic carbon content lower than $18 \mathrm{~g} \mathrm{~L}^{-1}$ and $\mathrm{C} / \mathrm{N}$ ratio less than 3.6 (Table 1). 
Table 1. Chemical composition of cassava wastewater used in the experiment

\begin{tabular}{|c|c|c|c|c|c|c|c|c|c|c|c|}
\hline $\mathrm{pH}$ & B & $\mathrm{Cu}$ & $\mathrm{Ca}$ & S & $\mathrm{Fe}$ & $\mathrm{P}_{2} \mathrm{O}_{5}$ & $\mathrm{Mg}$ & $\mathrm{Mn}$ & $\mathrm{N}$ & $\mathrm{K}_{2} \mathrm{O}$ & $\mathrm{Zn}$ \\
\hline & ----. & ------ & ------ & ------י- & ----- & $\overline{\mathrm{mg} \mathrm{L}^{-}}$ & & & & & - \\
\hline 4.42 & 990 & 750 & 220 & 1940 & 1140 & 270 & 160 & 190 & 1900 & 3000 & 220 \\
\hline
\end{tabular}

\subsection{Soil Collecting and Analysis}

Non-formed soil samples were collected at a depth of 0.0-0.15 $\mathrm{m}$ and the following physical attributes were evaluated: soil penetration resistance (PR): determined for a soil water potential of $100 \mathrm{kPa}$ and submitted to the bench model penetrometer MA 933; hydraulic conductivity of the saturated soil $\left(\mathrm{K}_{0}\right)$ : determined in the laboratory by the constant charge permeameter method; macroporosity (Ma), microporosity (Mi), total porosity (TP) and soil density (SD) determined by the methods described by Teixeira et al. (2017).

With the deformed samples the following indices were determined: the flocculation index (FI) obtained by the relation between total clay and dispersed clay in water, the sedimentation time of the sample being determined by Stokes' Law (Stokes, 1851) and clay determined by the pipette method and determination of the stability of the aggregates that was performed by means of the wet sieving according to Yoder (1936) expressed by means of the geometric average diameter of the aggregates $(\mathrm{GAD})$ and the weighted average diameter (WAD) as described by Donagema et al. (2011).

The chemical attributes evaluated were $\mathrm{pH}$, calcium $\left(\mathrm{Ca}^{2+}\right)$, magnesium $\left(\mathrm{Mg}^{2+}\right)$, exchangeable potassium $\left(\mathrm{K}^{+}\right)$, available phosphorus $(\mathrm{P})$, sodium $\left(\mathrm{Na}^{+}\right)$, potencial acidity $(\mathrm{H}+\mathrm{Al})$, effective cation exchange capacity $\left(\mathrm{CEC}_{\mathrm{t}}\right)$, potential cation exchange capacity $\left(\mathrm{CEC}_{\mathrm{T}}\right)$, base sum $(\mathrm{BS})$, base saturation $(\mathrm{V} \%)$, organic matter $(\mathrm{OM})$ and exchangeable aluminum (Al) (P. C. Teixeira, Donagema, Fontana, \& W. G. Teixeira, 2017).

\subsection{Collection of Vegetation}

At 90 days after the application of cassava wastewater, spontaneous vegetation was sampled using square plots of $0.25 \mathrm{~m}^{2}$ in five replications per treatment. The plants were cut to the height of the base, separated, identified and packaged in paper bags for further determination of dry matter yield. The mass of the dry matter was obtained after drying the samples in a forced air oven at $65^{\circ} \mathrm{C}$ for 48 hours.

\subsection{Statistical Analysis}

The statistical method used was based on univariate and multivariate analyzes. The univariate analysis was done using the Statistical software version 7.0 (Statsoft, 2004). The observed values of the attributes were submitted to analysis of variance, according to a randomized block design, and the significant effects were compared through the Tukey test at $5 \%$ probability. Thus, the means of the dry mass produced by the spontaneous vegetation in each treatment of mechanical preparation were compared, as well as the general averages of the physical and chemical attributes of the soil in the treatment of cassava wastewater and vegetation in the plots, distinguishing the joint and isolated effect of treatments.

The multivariate analysis was done with the help of SPSS software (Statistical Package for Social Sciences) version 25.0 and had as purpose to distinguish the effects of the presence or absence of cassava wastewaterin the physical and chemical attributes of the soil under the treatments of mechanical preparation. The Kaiser-Meyer-Olkin criterion (KMO) and Bartlett's sphericity test were used to analyze if the data can be submitted to the factorial analysis process, being considered acceptable the values assigned to the variables in the range (Table 1). The results obtained in this study are similar to those of the Bartlett sphericity test, with a significance level of $\mathrm{p}<0.05$, indicating that the matrix is factorizable (Sass \& Schmitt, 2010; Hair, Anderson, Tatham \& Black, 2005; Tabachnick \& Fidell, 2007). Thus, exploratory factorial analysis (AFE) and principal component analysis (PCA) were performed to reduce the set of soil attributes to the smallest number of explanatory variables (Widaman, 2007). The separation between the mechanical staging treatments and the cassava wastewater effect was performed using the set of attributes selected through Fisher's linear discriminant analysis (DA).

For PCA, only the main components (MCs) were used as eigenvalues greater than 1, since they are sufficient to explain most of the variation in the data set, according to the criterion suggested by Kaiser (1958). For graphical confirmation of MCs, the graphic method called the scree plot test or the Cattell test (Hair et al., 2005) was used. The summaries of the MCs were configured by the representation of eigenvalues and eigenvectors. 


\section{Results and Discussion}

\subsection{Univariate Analysis}

The addition of the cassava wastewater in the soil interfered significantly in the production of dry mass of the spontaneous vegetation (Table 2). In the plots where the application of cassava wastewater occurred, the productivity of dry mass of the vegetation was significantly higher than in the plots where there was no application, thus confirming its potential as a supplier of nutrients for the plants (Duarte et al., 2013; Magalhães et al., 2014; Souza et al., 2014) the results are presented in Table 1.

There was also a significant difference in the production of dry mass of the spontaneous vegetation within the treatments with mechanical preparation, and the treatments with 4 and 8 treatments presented the highest dry mass production and the treatments without preparation and with 12 preparations the smaller amount.

Table 2. Production of dry mass of spontaneous vegetation in the treatments of mechanical preparation with plowing + sorting on a yellow oxisol

\begin{tabular}{|c|c|c|}
\hline Treatments & Whit cassava wastewater & Whitout cassava wastewater \\
\hline & \multicolumn{2}{|c|}{ 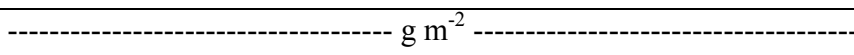 } \\
\hline T0 & $518.60 \mathrm{Ab}$ & $265.86 \mathrm{Bb}$ \\
\hline $\mathrm{T} 1$ & $784.26 \mathrm{Aa}$ & $648.73 \mathrm{Ba}$ \\
\hline $\mathrm{T} 2$ & $955.33 \mathrm{Aa}$ & $527.06 \mathrm{Ba}$ \\
\hline $\mathrm{T} 3$ & $503.20 \mathrm{Ab}$ & $220.80 \mathrm{Bb}$ \\
\hline
\end{tabular}

Note. Averages followed by the same letter, upper case and lower case in the column, do not differ from each other by the Tukey test at $5 \%$ probability.

Non-tillage may have hindered the growth of other species in the treatment without preparation, due to the historical predominance of Brachiaria decumbens Stapf. in the area, resulting in the least amount of dry mass in it. This condition may be associated to the allelopathic effects that forage of the genus Brachiaria possess, thus inhibiting the germination and development of other species (Rodrigues, Laura, Pereira, \& Deiss, 2012; Souza Filho, Pereira, \& Bayma, 2005). In the treatments with 4 and 8 mechanical preparations, the movement and the consequent exposure of the seed bank for the preparation and the addition of cassava wastewater and water contributed to the development of the plants. However, with 12 treatments, there was a decrease in the dry matter production of the spontaneous vegetation, which may be related to the unfavorable soil conditions generated by the slight decrease in $\mathrm{pH}$ and organic matter content (Figures 3 and 4).

The general averages of the physical attributes of the soil in relation to the vegetation and the application of cassava wastewater are shown in table 3 . According to the same the treatments promoted a significant difference only for the hydraulic conductivity of the saturated soil $\left(\mathrm{K}_{\mathrm{o}}\right)$ and macroporosity (Ma).

The highest value of Ma was found in the plots where the cassava wastewater was applied, with the vegetation maintenance $\left(\mathrm{MCV}=0.28 \mathrm{~m}^{3} \mathrm{~m}^{-3}\right)$ and the lowest value in the plots with the cassava wastewaterwithout vegetation (MSV $=0.25 \mathrm{~m}^{3} \mathrm{~m}^{-3}$ ). However, these values did not differ significantly from the plots where there was no application of cassava wastewater. The tendency of higher Ma values in the plots with maintenance and vegetation may be related to the contribution of cassava wastewateras a source of nutrients for the vegetation, thus helping in the root development, which may have promoted an indirect effect in the tendency to increase Ma. 
Table 3. Physical attributes of a yellow oxisol after mechanical preparation of plowing + harrowing in relation to the application of cassava wastewater and the presence of vegetation

\begin{tabular}{|c|c|c|c|c|c|c|c|c|c|}
\hline Tratments & $\mathrm{K}_{0}$ & $\mathrm{SD}$ & PR & $\mathrm{TP}$ & $\mathrm{Mi}$ & $\mathrm{Ma}$ & GAD & WAD & FI \\
\hline & $\mathrm{cm} \mathrm{h}^{-1}$ & $\mathrm{~g} \mathrm{~cm}^{-3}$ & $\mathrm{MPa}$ & \multicolumn{3}{|c|}{ - } & \multicolumn{2}{|c|}{--------- mm --------- } & $\%$ \\
\hline WSV & $23.63 \mathrm{~B}$ & $1.56 \mathrm{~A}$ & $2.70 \mathrm{~A}$ & $0.40 \mathrm{~A}$ & $0.13 \mathrm{~A}$ & $0.26 \mathrm{AB}$ & $1.19 \mathrm{~A}$ & $1.67 \mathrm{~A}$ & $13.81 \mathrm{~A}$ \\
\hline WCV & $32.01 \mathrm{AB}$ & $1.56 \mathrm{~A}$ & $2.57 \mathrm{~A}$ & $0.39 \mathrm{~A}$ & $0.12 \mathrm{~A}$ & $0.26 \mathrm{AB}$ & $1.27 \mathrm{~A}$ & $1.75 \mathrm{~A}$ & $13.76 \mathrm{~A}$ \\
\hline MSV & $24.36 \mathrm{~B}$ & $1.57 \mathrm{~A}$ & $2.04 \mathrm{~A}$ & $0.39 \mathrm{~A}$ & $0.12 \mathrm{~A}$ & $0.25 \mathrm{~B}$ & $1.18 \mathrm{~A}$ & $1.65 \mathrm{~A}$ & $13.98 \mathrm{~A}$ \\
\hline $\mathrm{MCV}$ & $37.34 \mathrm{~A}$ & $1.50 \mathrm{~A}$ & $1.99 \mathrm{~A}$ & $0.41 \mathrm{~A}$ & $0.12 \mathrm{~A}$ & $0.28 \mathrm{~A}$ & $1.26 \mathrm{~A}$ & $1.70 \mathrm{~A}$ & $15.21 \mathrm{~A}$ \\
\hline $\mathrm{CV}(\%)$ & 44.38 & 7.17 & 46.45 & 7.62 & 6.00 & 10.78 & 19.92 & 17.19 & 43.38 \\
\hline
\end{tabular}

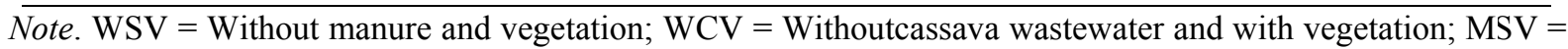
With cassava wastewater and without vegetation; $\mathrm{MCV}=$ With cassava wastewater and vegetation; $\mathrm{K}_{0}=$ hydraulic conductivity of saturated soil; $\mathrm{SD}=$ soil density; $\mathrm{TP}=$ Total porosity; $\mathrm{Mi}=$ Microporosity; $\mathrm{Ma}=$ Macroporosity; $\mathrm{PR}=$ resistance to soil penetration at $0.1 \mathrm{MPa}$ humidity; GAD = geometric mean diameter of aggregates; $\mathrm{WAD}=$ weighted average diameter of aggregates; FI = flocculation index. *Averages followed by the same letter in the column do not differ from each other by the Tukey test at $5 \%$ probability.

The vegetation presented an isolated effect on $\mathrm{K}_{0}$, and the value of this attribute was higher in the vegetation plots within each treatment, independent of the application of cassava wastewater (Figure 2). Although GAD and WAD did not have an isolated effect of vegetation, Ma values tended to be higher in vegetated plots, which favored increase of $\mathrm{K}_{0}$ (Table 3). This effect can be attributed to the deposition of organic matter via root exudation, which favors soil aggregation, especially in areas close to the roots of the plants, resulting in a consequent increase in soil hydraulic conductivity (Salton et al., 2008; Strudley, Green, \& Ascough Ii, 2008).

The application of cassava wastewater within each treatment of mechanical preparation captured the resistance to penetration (PR), being the lowest values found in the plots with the application of the same (Figure 2), in which there was also a trend of higher values of Ma, which may explain the reduction of PR.
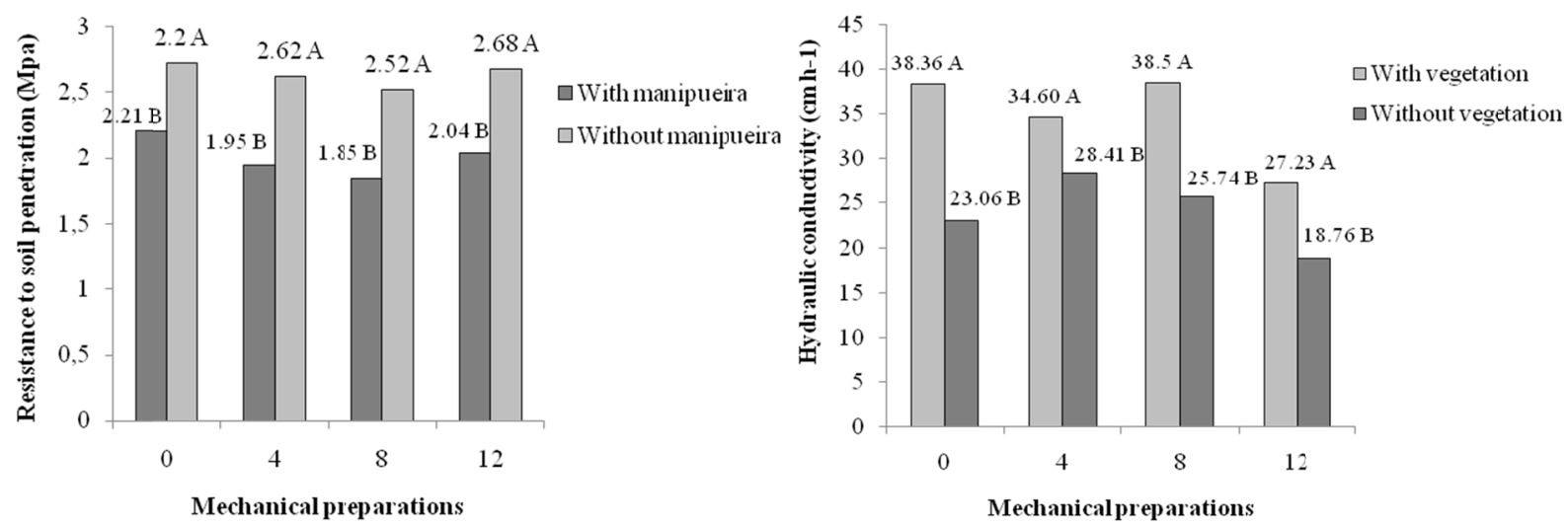

Figure 2. Soil resistance penetration (PR) in the plots with and without application of cassava wastewater (manipueira) and hydraulic conductivity of the saturated soil $\left(\mathrm{K}_{0}\right)$ in the plots with and without vegetation, in the treatments of mechanical preparation of plowing + sorting in Yellow Oxisol

Note. Means followed by the same letter did not differ among themselves by the Tukey test at $5 \%$ probability

The general averages of chemical attributes of the soil in relation to the vegetation and the application of cassava wastewater presented significant difference for the $\mathrm{pH}$ and the content of $\mathrm{P}$ and $\mathrm{K}^{+}$(Table 4). 
Table 4. Chemical attributes of a yellow oxisol after mechanical preparation of plowing + harrowing in relation to the application of cassava wastewater and the presence of vegetation

\begin{tabular}{|c|c|c|c|c|c|c|c|c|c|c|c|}
\hline Tratments & $\mathrm{pH}$ & $\mathrm{P}$ & $\mathrm{K}^{+}$ & $\mathrm{Ca}^{2^{+}}$ & $\mathrm{Mg}^{2^{+}}$ & $\mathrm{H}+\mathrm{Al}$ & BS & $\mathrm{CEC}_{(\mathrm{t})}$ & $\mathrm{CEC}_{(\mathrm{T})}$ & $\mathrm{OM}$ & $\mathrm{V}$ \\
\hline & & \multicolumn{2}{|c|}{------ $\mathrm{mg} \mathrm{dm}^{-3}$------- } & \multicolumn{6}{|c|}{------------------------- $\mathrm{cmol}_{(\mathrm{c})} \mathrm{dm}^{-3}$------------------- } & \multicolumn{2}{|c|}{--------- \% --------- } \\
\hline WSV & $6.23 \mathrm{AB}$ & $2.80 \mathrm{AB}$ & $18.57 \mathrm{AB}$ & $2.12 \mathrm{~A}$ & $1.07 \mathrm{~A}$ & $1.27 \mathrm{~A}$ & $3.23 \mathrm{~A}$ & $3.23 \mathrm{~A}$ & $4.50 \mathrm{~A}$ & $1.41 \mathrm{~A}$ & $71.89 \mathrm{~A}$ \\
\hline WCV & $6.32 \mathrm{~A}$ & $2.25 \mathrm{~B}$ & $15.24 \mathrm{~B}$ & $2.05 \mathrm{~A}$ & $1.17 \mathrm{~A}$ & $1.21 \mathrm{~A}$ & $3.23 \mathrm{~A}$ & $3.23 \mathrm{~A}$ & $4.44 \mathrm{~A}$ & $1.43 \mathrm{~A}$ & $72.49 \mathrm{~A}$ \\
\hline MSV & $6.00 \mathrm{C}$ & $3.44 \mathrm{~A}$ & $17.59 \mathrm{~B}$ & $1.92 \mathrm{~A}$ & $1.21 \mathrm{~A}$ & $1.24 \mathrm{~A}$ & $3.18 \mathrm{~A}$ & $3.18 \mathrm{~A}$ & $4.42 \mathrm{~A}$ & $1.24 \mathrm{~A}$ & $71.52 \mathrm{~A}$ \\
\hline $\mathrm{MCV}$ & $6.13 \mathrm{BC}$ & $2.70 \mathrm{~B}$ & $23.65 \mathrm{~A}$ & $1.87 \mathrm{~A}$ & $1.08 \mathrm{~A}$ & $1.11 \mathrm{~A}$ & $3.01 \mathrm{~A}$ & $3.01 \mathrm{~A}$ & $4.12 \mathrm{~A}$ & $1.51 \mathrm{~A}$ & $72.64 \mathrm{~A}$ \\
\hline CV $(\%)$ & 3.04 & 29.40 & 37.35 & 15.26 & 23.02 & 24.69 & 15.14 & 15.14 & 13.05 & 39.71 & 7.52 \\
\hline
\end{tabular}

Note. $\mathrm{WSV}=$ Without manure and vegetation; $\mathrm{WCV}=$ Without cassava wastewater and with vegetation; $\mathrm{MSV}=$ With cassava wastewater and without vegetation; $\mathrm{MCV}=$ With cassava wastewater and vegetation; $\mathrm{BS}=\mathrm{Sum}$ of bases; CEC ( $\mathrm{t})=$ Effective cation exchange capacity; CEC $(\mathrm{T})=$ Potential cation exchange capacity; OM = organic matter; $\mathrm{V}=$ Base Saturation. No levels of $\mathrm{Al}^{3+}$ were found * Averages followed by the same letter in the column do not differ among themselves by the Tukey test at $5 \%$ probability.

In general, the $\mathrm{pH}$ values (Table 4) are between the limit of medium to weak acidity (Ribeiro, Alvarez, \& Guimarães, 1999). Soil pH decreased in the plots where the cassava wastewater was applied (Figure 4). This result may be associated with the low $\mathrm{pH}$ of the applied manure $(\mathrm{pH}=4.42)$, due to the organic acids present in it. A similar effect was also observed by Cardoso et al. (2009), when applying to the soil the cassava wastewater $(\mathrm{pH}=3.6)$. In relation to the intensification of the preparation, the reduction of soil $\mathrm{pH}$ can be related to the accelerated decomposition of the organic matter, promoted by the intensification of the preparation (Figure 3), which releases organic acids in the soil (Pavinato \& Rosolem, 2008) which can also explain the isolated effect of vegetation on the $\mathrm{pH}$, with the lowest values being found in the unplanted plots, ie, where the soil is not covered, conditions where the organic matter decomposition is higher (Figure 5).

Another effect of the cassava wastewater application was the reduction of $\mathrm{Ca}^{2+}$ contents. This condition can be attributed to the large amount of $\mathrm{K}^{+}$supplied by the cassava wastewater, which may have replaced the $\mathrm{Ca}^{2+}$ on the exchange surface of the mineral particles, displacing it to the soil solution, where it reacted with the $\mathrm{SO}_{4}{ }^{2-}$ also supplied by the cassava wastewater (Table 1), forming a neutral molecule, calcium sulphate, easily leachable (Sousa, Miranda, \& Oliveira, 2007; Santi et al., 2012).

Within the general averages of the treatments, the highest levels of $\mathrm{P}$ were observed in the plots without vegetation, according to Table 4 (WSV $=2.80$ and $\mathrm{MSV}=3.44 \mathrm{mg} \mathrm{dm}^{-3}$ ), as well as in the isolated effect of the presence of vegetation on such element (Figure 5). This behavior may have occurred due to the fact that the succession plants extracted this nutrient available in the soil, since it was in small quantity (Cain, Bowman, \& Hacker, 2018).

The effect of the intensification of the preparation on the content of $\mathrm{P}$ was variable, increased between 0 and 4 treatments, and decreased from this until the maximum preparation of 12, with significant effects between them. This behavior may be related to the reduction of soil organic matter (OM) with the intensification of the preparation (Figure 3), so that, in principle, soil rotation incorporates the biomass present on the soil surface. However, the intensification of the preparation strongly accelerated such decomposition, reducing the OM content and, consequently, the P contents. Similar effects of OM loss with intensive soil preparation were also observed by Bayer, Mielniczuk, and Martin-Neto (2000), and Bertol et al. (2004). 


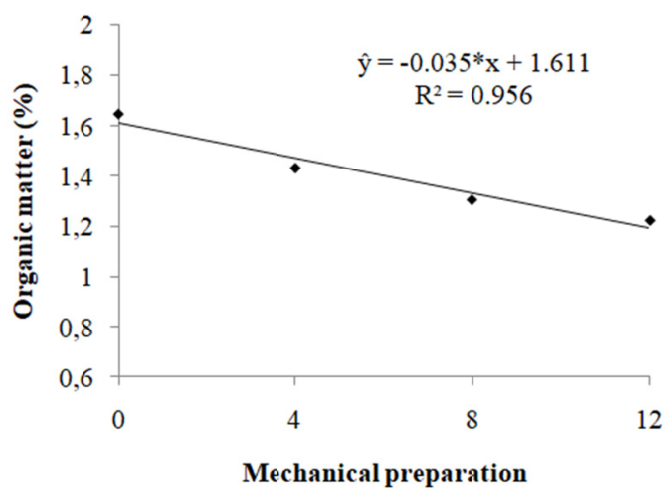

Figure 3. Soil organic matter $(\mathrm{OM})$ as a function of the mechanical preparation of plowing + harrowing in a yellow oxisol

Note. *Significant at $5 \%$ probability.

It was also verified that the application of cassava wastewater increased the $\mathrm{P}$ contents in all mechanical preparation treatments, except in 12 treatments, in which there was no significant difference (Figure 4).

The increase of $\mathrm{P}$ with the application of cassava wastewater can be related not only to the presence of such element in the composition of the same, but also to the high S content of thecassava wastewater, because the use of the extractive solution of $\mathrm{P}$ is based on solubilization $(\mathrm{pH}$ of the cassava wastewater $=4.42)$ and the action of the sulfate anion $\left(\mathrm{SO}_{4}{ }^{2-}\right)$, which is able to displace the phosphates adsorbed in the positive charges of the soil, constituting a mechanism of exchange, and restricting the process of readsorption of the newly extracted phosphates (Jones, 2001; Novais, Smyth, \& Nunes, 2007; Silva, Eira, Barreto, Pérez, \& Silva, 1998). The increase of $\mathrm{P}$ with the addition of cassava wastewater also corroborates with results obtained by Mélo et al. (2005), and Duarte et al. (2013).
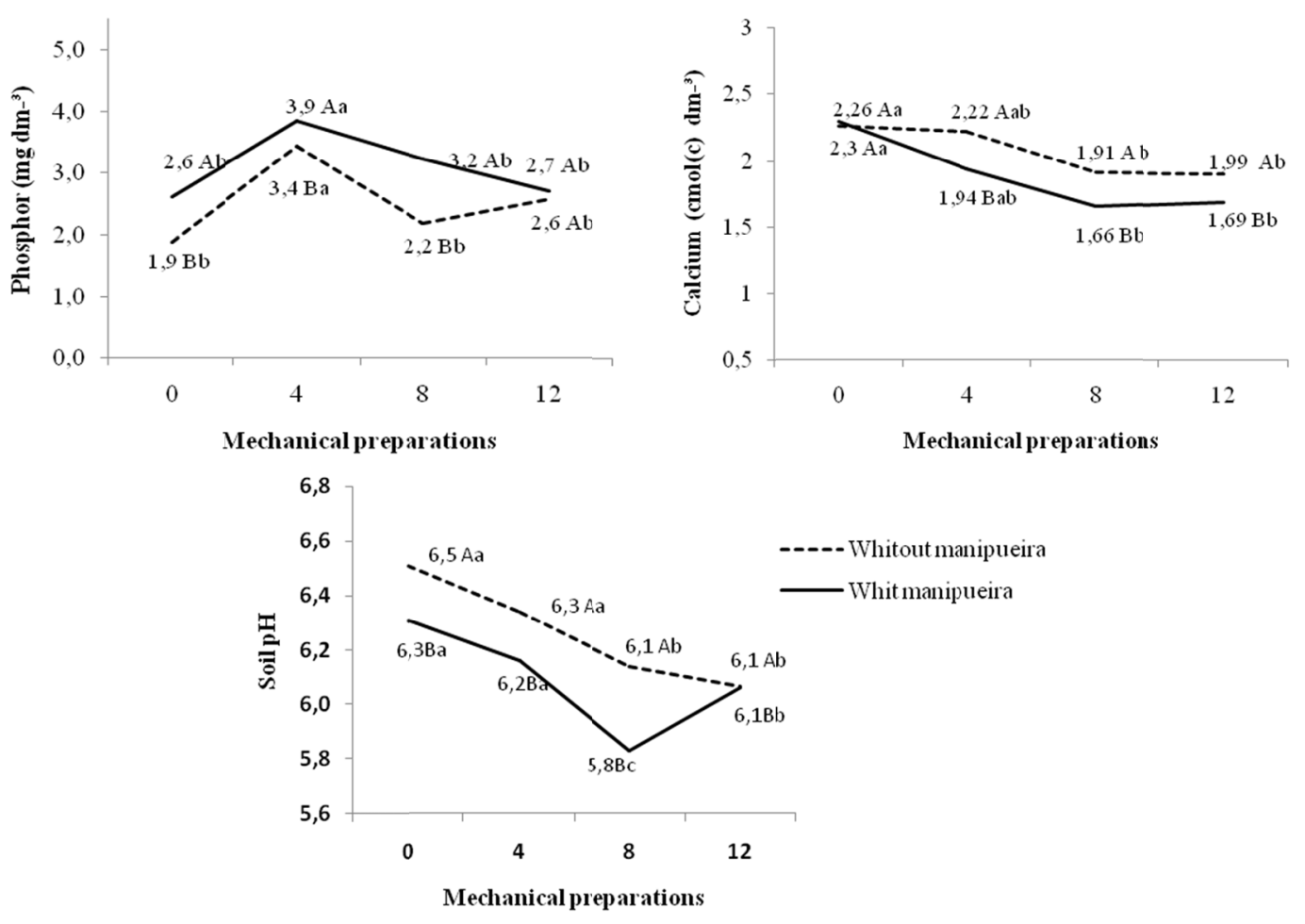

Figure 4. Phosphorus $(\mathrm{P})$ and calcium $\left(\mathrm{Ca}^{2+}\right)$ contents and $\mathrm{pH}$ of a yellow oxisol submitted to mechanical preparation of plowing + harrowing in relation to the presence and absence of cassava wastewater

Note. Means followed by the same letter, uppercase between the functions and lowercase between the mechanical preparations, did not differ among themselves by the Tukey test at $5 \%$ probability. 
The values of $\mathrm{K}^{+}$showed a significant difference in the general averages of treatments, with the highest values found in the plots with mango tree and vegetation $\left(\mathrm{MCV}=23.65 \mathrm{mg} \mathrm{dm}^{-3}\right)$ and without cassava wastewater and vegetation (WSV $=18.57 \mathrm{mg} \mathrm{dm}^{-3}$ ) (Table 4). In addition, this nutrient had an isolated effect of the vegetation inside the mechanical preparation treatments, as well as the $\mathrm{P}$ and the soil $\mathrm{pH}$ (Figure 5).
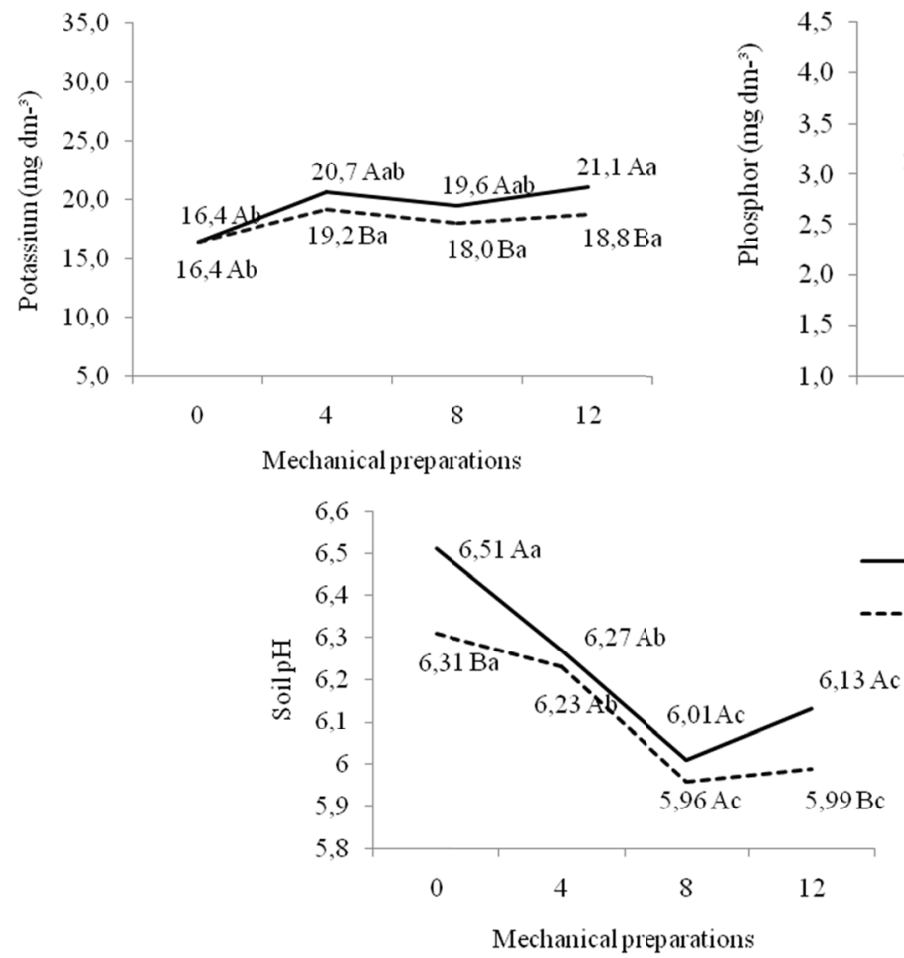

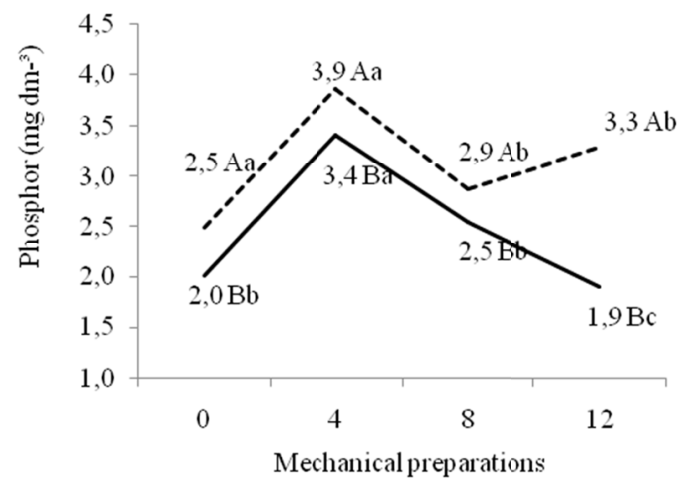

With vegetation

- Without vegetation

Figure 5. Potassium $\left(\mathrm{K}^{+}\right)$and phosphorus $(\mathrm{P})$ contents and $\mathrm{pH}$ of a yellow oxisol subjected to mechanical preparation of plowing + gradation in relation to the presence and absence of spontaneous vegetation

Note. Means followed by the same letter, uppercase between the functions and lowercase between the mechanical preparations, did not differ among themselves by the Tukey test at $5 \%$ probability.

The $\mathrm{K}^{+}$contents were higher in the vegetation plots, except for the unprepared treatment, where they were statistically the same, which may be associated with biomass deposited in the soil during the plant cycle, which constitute a rich $\mathrm{K}^{+}$source (Guadagnin, Bertol, Cassol, \& Amaral, 2005).

\subsection{Multivariate Analysis}

The complete factorial analysis of the values extracted by the scree plot, considering as significant only the eigenvalues greater than 1 , allowed to identify two components, both for the plots without cassava wastewater and for the plots with cassava wastewater (Figure 6). 


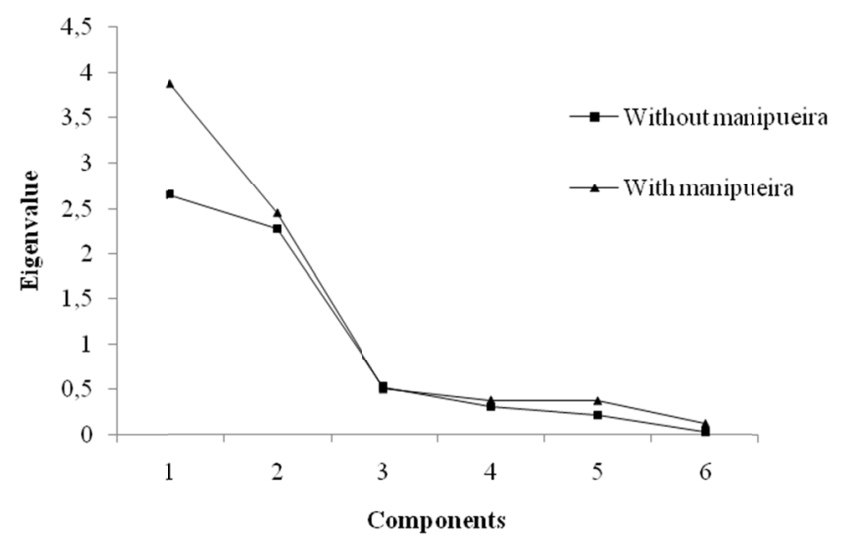

Figure 6. Analysis of the physical and chemical attributes variation in a yellow oxisol by the scree plot method submitted to mechanical preparation of plowing + harrowing in the presence and absence of cassava wastewater (manipueira)

It is observed that the first two factors presented the highest eigenvalues, with the first main component (MC1) accounting for 2,647 and the second main component (MC2) accounting for 2,269 of the variance explained among the samples of the mechanical preparation treatments in the non-application plots while the MC1 was responsible for 3,877 and MC2 for 2,447 (Figure 6). Therefore, the first two components were responsible for a greater variance with values greater than 1 .

The preliminary analysis of the main components was performed with all physical and chemical attributes. The weights of each soil attribute constituting the linear combination were better visualized and confirmed when using the Varimax rotation with Kaiser Normalization and convergent rotation in three interactions. However, among the attributes of the soil analyzed only the physical attributes TP, Ma, SD and chemicals BS, $\mathrm{Ca}, \mathrm{Mg}, \mathrm{pH}$ and $\mathrm{V} \%$ met the assumption of orthogonality between the components, considering the set of samples with or without cassava wastewater(Table 5).

Table 5. Correlation matrix of the main components rotated of the physical and chemical attributes of the soil, eigenvalue, percentage of variation in MCs and total variation explained in the samples with and without application of cassava wastewaterin the treatments of mechanical preparation of plowing + harrowing

\begin{tabular}{|c|c|c|c|c|}
\hline \multirow{2}{*}{ Atributos } & \multicolumn{2}{|c|}{ Withoutcassava wastewater } & \multicolumn{2}{|c|}{ Withcassava wastewater } \\
\hline & $\mathrm{MC1}$ & $\mathrm{MC} 2$ & $\mathrm{MC1}$ & $\mathrm{MC} 2$ \\
\hline Macroporosity (Ma) & 0.958 & 0.043 & 0.005 & 0.962 \\
\hline Total porosity (TP) & 0.957 & 0.001 & 0.082 & 0.958 \\
\hline Soil density (SD) & -0.828 & 0.127 & -0.029 & -0.845 \\
\hline Sum of bases (BS) & 0.090 & 0.873 & 0.968 & -0.088 \\
\hline Calcium $(\mathrm{Ca})$ & 0.134 & 0.854 & 0.894 & 0.092 \\
\hline Magnesium (Mg) & -0.139 & 0.917 & 0.736 & -0.348 \\
\hline $\mathrm{pH}$ of the soil $(\mathrm{pH})$ & - & - & 0.833 & 0.270 \\
\hline Base Saturation (V) & - & - & 0.924 & 0.157 \\
\hline Eigenvalue & 2.647 & 2.269 & 3,877 & 2,447 \\
\hline Explainedvariance (\%) & 44.12 & 37.82 & 48,47 & 34,34 \\
\hline Total variance $(\%)$ & 81.94 & & 82.81 & \\
\hline
\end{tabular}

Note. ${ }^{*}$ Values were not assigned to attribute components that did not meet the orthogonality assumptions.

In the analyzes of the samples in the plots without application of cassava wastewater, MC1 explained $44.12 \%$ of the variability of the observed data, consisting of the physical attributes of the soil Ma (0.958), TP (0.957) with positive intercorrelation and SD (-0.828), with negative correlation, and therefore, the first two attributes are inversely proportional to the latter. The MC2 explained $37.82 \%$ of the data, constituted by soil chemical attributes BS (0.873), $\mathrm{Ca}(0.854)$ and $\mathrm{Mg}(0.917)$. The two MCs were responsible for $82.94 \%$ of the variance 
explained. With the application of the cassava wastewater, the CP1 explained $48.47 \%$ of the data and is constituted by the chemical attributes BS (0.968), Ca (0.894), Mg (0.736), pH (0.833) and V (0.924). The MC2 explained $34.34 \%$ of the data with the physical attributes Ma (0.962), TP (0.958) and SD (-0.845), with the two MCs accounting for $82.81 \%$ of the total variance explained (Table 5).

According to the results, the application of cassava wastewater in the soil generally modified the behavior of the variables that best explain the results, so that the chemical and physical attributes revealed the interaction of the mechanical preparation treatments versus treatments with and without cassava wastewater (Figure 7). It is observed that the $\mathrm{V} \%$ and $\mathrm{pH}$ variables are composed of the chemical attributes set (MC1). This behavior can be attributed to the low $\mathrm{pH}$ and the rich composition of the cassava wastewater (Table 1), thus influencing more strongly the chemical attributes $\mathrm{BS}, \mathrm{Ca}, \mathrm{Mg}, \mathrm{V} \%$ and soil $\mathrm{pH}$. Therefore there was an inversion of importance of the chemical and physical attributes in the variability of the mechanical preparations according to the application of cassava wastewater or not.
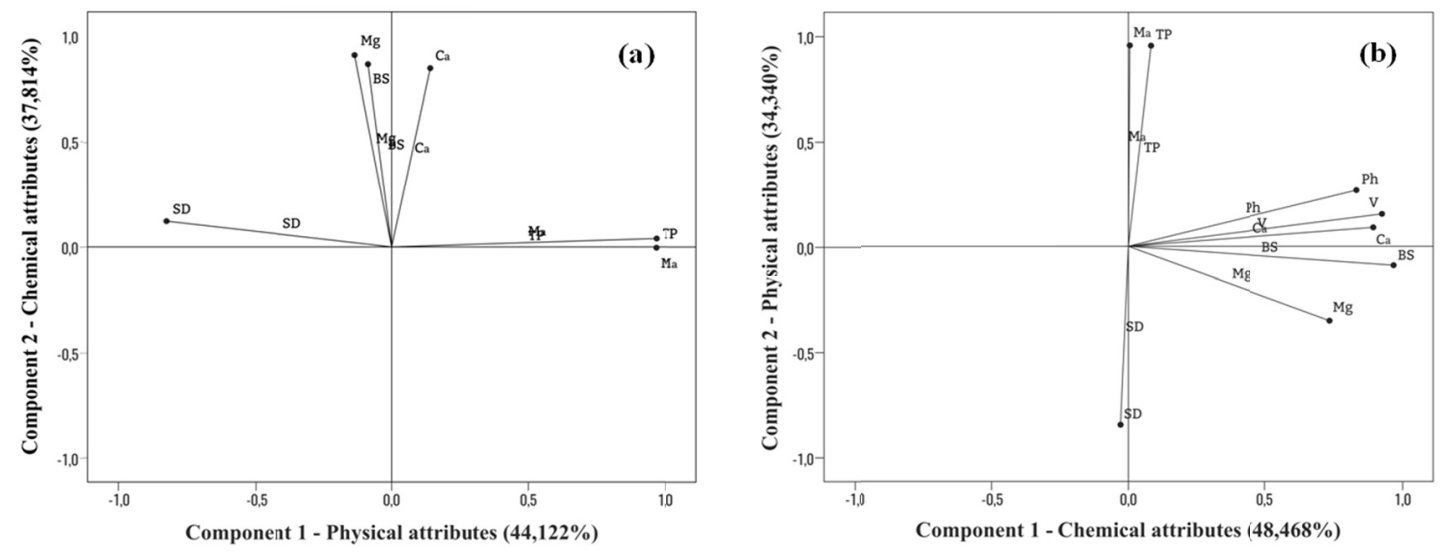

Figure 7. Eigenvalues and eigenvectors of the configuration of the physical and chemical attributes of a yellow oxisol under mechanical preparation of plowing + harrow evaluated in the absence (a) and presence (b) ofcassava wastewater

In order to identify the attributes and to relate the discriminant functions to the study factors: Mechanical and manipulative preparation, the complementary analysis was performed, which is represented in the dispersion diagram of the attributes that express how the correlation structure between originals and discriminants behaves, in canonical plane 2-3. Thus, it was possible to synthesize the results in two sets shown in figure 8a, which superimposed on figure $8 \mathrm{~b}$, reveals in the discriminant plane that the function 1 represented by the physical soil indicators $\mathrm{Ma}$ (0.964), TP (0.962) and SD (-0.838) were the most important attributes, explaining 52.32\% of the variability among the treatments of mechanical strength, as observed by figure $8 \mathrm{~b}$ in the horizontal distribution of the centroids of the plots. While function 2 indicates in the point projection that the chemical attributes $\mathrm{pH}$ (0.860) and $\mathrm{V}(0.838)$ discriminate the presence and absence of the cassava wastewater, explaining $28.55 \%$ of the variability in the vertical distribution of the centroids (Figure 8b). The two functions explain $80.87 \%$ of the variations of the attributes of the soil samples. 

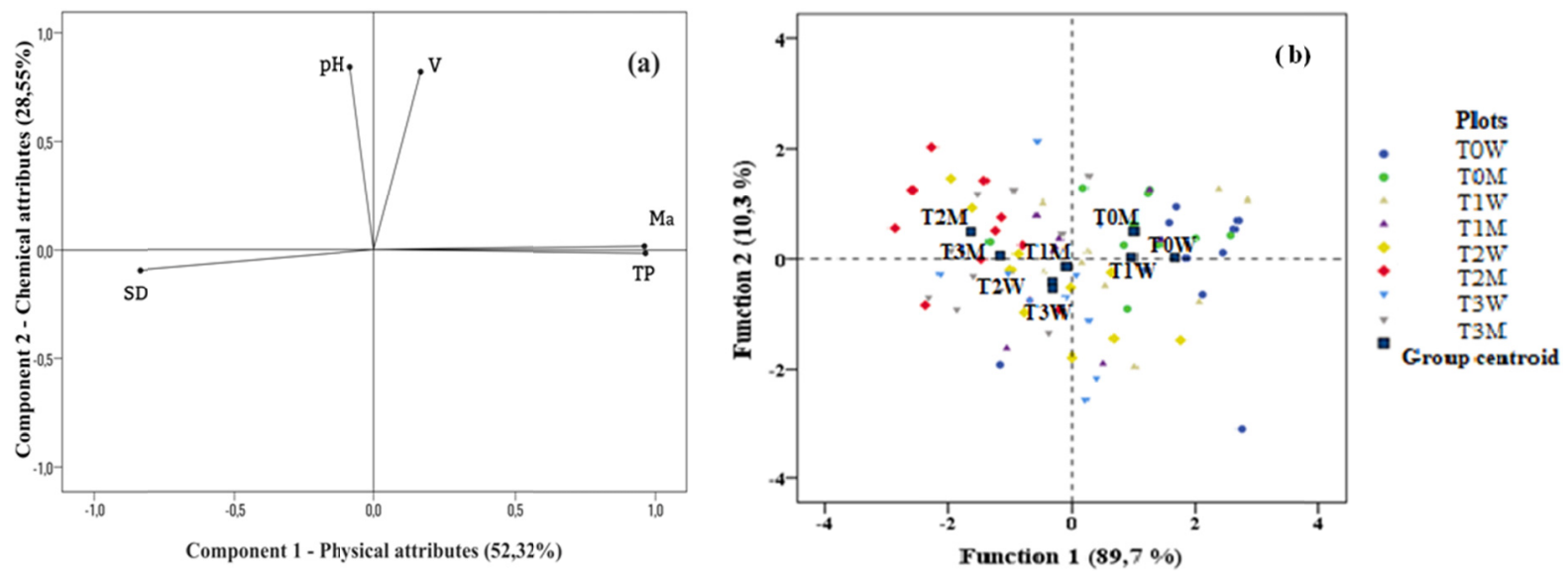

Figure 8. Eigenvalues and eigenvectors of the configuration (a) and distribution order diagram (b) of the soil attributes evaluated with and without application of cassava wastewater in relation to the treatments of mechanical preparation of plowing + harrow

Note. T0W: Without mechanical preparation and without cassava wastewater; T0M: No mechanical preparation with cassava wastewater; T1W: 4 mechanical preparation without cassava wastewater; T1M: 4 mechanical preparations with cassava wastewater; T2W: 8 mechanical preparation without cassava wastewater; T2M: 8 mechanical preparation with cassava wastewater; $\mathrm{T} 3 \mathrm{~W}: 12$ mechanical preparation without cassava wastewater; T3M: 12 mechanical preparations with cassava wastewater.

In relation to the presence (M) and absence (A) of cassava wastewater the following Fisher discriminant functions were generated:

$$
\begin{aligned}
A & =-323.188+113.102 \mathrm{pH}-0.883 V \\
M & =-300.731+108.225 \mathrm{pH}-0.777 V
\end{aligned}
$$

It can be seen that, according to the coefficients of the functions, the $\mathrm{pH}$ influence was significantly higher than the $\mathrm{V} \%$, and these two variables determine a lower absolute value in the function scores on the cassava wastewater effect. The results of the classification of the samples are shown in Table 6, and show that, on average, $72.5 \%$ of the samples were correctly grouped in their respective groups.

Generally through the projection of the scatterplots, it is understood (Figure 8) that the values of $\mathrm{pH}, \mathrm{V} \%$, Ma, TP observed in the samples decreased linearly asthere was an increase inthe intensity of the mechanical preparation whereas the values of SD increased, regardless of the presence or absence of cassava wastewater. These effects are due to loss of soil fertility, promoted by intensive preparation and reduction of organic matter, which directly affects the stability of aggregates, promoting their decrease, increasing soil density and compaction processes (Bronick \& Lal, 2004; Montanari et al., 2010), with the effects on OM levels observed in Figure 3. Already the values of $\mathrm{V} \%$ and $\mathrm{pH}$ had their values decreased in the samples with the use of cassava wastewater, regardless of the intensity of the preparation mechanical. For $\mathrm{pH}$, this condition proves the results of the univariate and for $\mathrm{V} \%$, the reduction of $\mathrm{Ca}^{2+}$ with the application of cassava wastewater may have influenced its decrease, albeit in a less accentuated way.

\section{Conclusion}

The application of cassava wastewater significantly increased the dry mass productivity of the spontaneous vegetation in all the treatments of mechanical preparation.

The values of $\mathrm{pH}, \mathrm{V} \%$, Ma, TP observed in the samples decreased linearly with the increase of the intensity of the mechanical preparation and the values of SD increased.

The physical attributes $\mathrm{K}_{0}$ and Ma had a significant effect of cassava wastewater application and maintenance of the spontaneous vegetation in the soil.

The maintenance of spontaneous vegetation in the soil increased $\mathrm{K}^{+}$and soil $\mathrm{pH}$ and reduced the levels of $\mathrm{P}$.

The application of cassava wastewater reduced $\mathrm{PR}, \mathrm{pH}, \mathrm{V} \%$ and $\mathrm{Ca}^{2+}$ contents and increased the contents of $\mathrm{P}$. 


\section{References}

Assis, R. L., \& Lanças, K. P. (2010). Agregação de um Nitossolo Vermelho Distroférricosob sistemas de plantio direto, preparo convencional e mata nativa. Revista Engenharia Agrícola, 30, 58-66. https://doi.org/ 10.1590/S0100-69162010000100006

Bayer, C., Mielniczuk, J., \& Martin Neto, L. (2000). Efeito de sistemas de preparo e de cultura na dinâmica da matéria orgânica e na mitigação das emissões de $\mathrm{CO}_{2}$. Revista Brasileira de Ciência do Solo, 24(3), 599-607. https://doi.org/10.1590/S0100-06832000000300013

Bertol, I., Schick, J., Massariol, J. M., Reis, E. F., \& Dilly, L. (2000). Propriedades físicas de um Cambissolo HúmicoÁlico afetadas pelo manejo do solo. Revista Ciência Rural, 30, 91-95. https://doi.org/ 10.1590/S0103-84782000000100015

Bertol, I., Albuquerque, J. A., Leite, D., Amaral, A. J., \& Zoldan Junior, W. A. (2004). Propriedades físicas do solo sob preparo convencional e semeadura direta em rotação e sucessão de culturas, comparadas às do campo nativo. Revista Brasileira de Ciência do Solo, 28(1). https://doi.org/10.1590/S0100-06832004000 100015

Bezerra, M. G. S., Silva, G. G. C., Difante, G. Dos S., Emerenciano Neto, J. V., Oliveira, E. M. M., \& Oliveira, L. E. C. (2017). Cassava wastewater as organicfertilizer in 'Marandu' grasspasture. Revista Brasileira de Engenharia Agrícola e Ambiental, 21(6), 404-409. https://doi.org/10.1590/1807-1929/agriambi.v21n6 p404-409

Blanco, H., \& Lal, R. (2010). Soil resilience and conservation. In H. Blanco, \& R. Lal (Eds.), Principles of soil conservation and management (pp. 15-33). Columbus, Springer Science Business Media. https://doi.org/ 10.1007/978-1-4020-8709-7_16

Bronick, C. J., \& Lal, R. (2005). Soil structure and management: A review. Geoderma, 124(1-2), 3-22. https://doi.org/10.1016/j.geoderma.2004.03.005

Cabral, J. R., Freitas, P. S. L., Bertonha, A., \& Muniz, A. S. (2010). Effects of wastewater from a cassava industry on soil chemistry and crop yield of lopsided oats (Avena strigosa Schreb). Brasilian Archives of Biology and Technology, 53(1), 19-26. https://doi.org/10.1590/S1516-89132010000100003

Cain, M. L., Bowman, W. D., \& Hacker, S. D. (2018). Ecologia (3rd ed.). Porto Alegre: Artmed.

Cardoso, E., Cardoso, D., Cristiano, M., Silva, L., Back, A. J., Bernadim, A. M., \& Paula, M. M. S. (2009). Use of manihot esculenta, crantz processing residue as biofertilizer in corn crops. Research Journal of Agronomy, 3(1), 1-8.

Chiochetta, C. G., Cotelle, S., Masfaraud, J. F., Toumi, H., Quaranta, G., Adani, F., \& Radetski, C. M. (2016). Use of agro-industrial organic sludge amendment to remediate degraded soil: Chemical and eco (geno) toxicological differences between fresh and stabilized sludge and establishment of application rates. Environmental Science and Pollution Research, 23(4), 3018-3025. https://doi.org/10.1007/s11356-015 $-5310-0$

Costa, F. S., Albuquerque, J. A., Bayer, C., Fontoura, S. M. V., \& Wobeto, C. (2003). Propriedades físicas de um Latossolo Bruno afetadas pelos sistemas de plantio direto e prepare convencional. Revista Brasileira de Ciência do Solo, 27, 527-535. https://doi.org/10.1590/S0100-06832003000300014

Da Silva Júnior, J. J., Coelho, E. F., Santa'ana, A. V., Santana Júnior, E. B., \& Pamponet, A. J. M. (2012). Uso damanipueira na bananeira 'Terra Maranhão'e seus efeitos no solo e na produtividade. Irriga, 17(3), 353. https://doi.org/10.15809/irriga.2012v17n3p353

Da Silva, A. P. M., Bono, J. A. M., \& Pereira, F. De A. R. (2014). Aplicação de vinhaça na cultura da cana-de-açúcar: Efeito no solo e na produtividade de colmos. Revista Brasileira de Engenharia Agricola e Ambiental, 18(1), 38-43. https://doi.org/10.1590/S1415-43662014000100006

Dantas, M. S. M., Rolim, M. M., Duarte, A. De S., Pedrosa, E. M. R., Tabosa, J. N., \& Dantas, D. Da C. (2015). Growth of sunflower fertilized with liquid waste from processing of cassava. Revista Brasileira de Engenharia Agrícola e Ambiental, 19(4), 350-357. https://doi.org/10.1590/1807-1929/agriambi. v19n4p350-357

De Araújo, N. C., Guimarães, P. L. F., Oliveira, S. J. C., De Lima, V. L. A., Bandeira F. De A., \& De Araújo, F. D. A. C. (2014). Quantificação da geração de resíduos em casas de farinha no estado da Paraíba. Revista Monografias Ambientais, 13(5), 3793-3799. https://doi.org/10.5902/2236130814984 
Donagema, G. K., Campos, D. V. B., Calderano, S. B., Teixeira, W. G., \& Viana, J. H. M. (2011). Manual de métodos de análise de solo (2nd ed.). Rio de Janeiro: Embrapa Solos.

Duarte, A. de S., Silva, E. F. de F., Rolim, M. M., Ferreira, R. F. de A. E. L., Malheiros, S. M. M., \& Albuquerque, F. da S. (2012). Use of different doses of cassava wastewater in lettucecrop in substitution of mineral fertilizer. Revista Brasileira de Engenharia Agrícola e Ambiental, 16(3), 262-267. https://doi.org/10.1590/S1415-43662012000300005

Duarte, A. S., Rolim, M. M., Silva, F. F., Pedrosa, E. M. R., Albuquerque, F. S., \& Magalhães, A. G. (2013). Alterações dos atributos físicos e químicos de um Neossolo após aplicação de doses de manipueira. Revista Brasileira de Engenharia Agricola e Ambiental, 17, 938-946. https://doi.org/10.1590/S1415-436620130 00900005

Embrapa (Empresa Brasileira de Pesquisa Agropecuária). (2016). Boletim meteorológico da estação convencional de Cruz das Almas, BA: Variabilidade e tendências climáticas. Embrapa Mandioca e Fruticultura-Documentos (INFOTECA-E).

Falleiro, R. M., Souza, C. M., Silva, C. S. W.,Sediyama, C. S., Silva, A. A., \& Fagundes, J. L. (2003). Influence of tillage systems on the chemical and physical attributes of a soil. Revista Brasileira de Ciência do Solo, 27, 1097-1104. https://doi.org/10.1590/S0100-06832003000600014

Ferreira, T., Ferreira, S. C. C., Araujo, N., Oliveira, S., \& Gonçalves, C. (2012). Estudo agronômico da espiga do milho (Zea mays L.) fertirrigado com manipueira. Engenharia Ambiental: Pesquisa e Tecnologia, 9(4), 152-163.

Ferreira, W. de A., Botelho, S. M., Cardoso, E. M. R., \& Poltronieri, M. C. (2001). Manipueira: Um adubo orgânico em potencial. Belém: Embrapa Amazônia Oriental.

Gatiboni, C. L., Saggin, A., Brunetto, G., Horn, D., Flores Cassol, J. P., Dos Santos, D. R., \& Kaminski, J. (2003). Alterações nos atributos químicos de solo arenoso pela calagem superficial no sistema plantio direto consolidado. Revista Ciência Rural, 33(2), 283-290. https://doi.org/10.1590/S0103-84782003000200016

Guadagnin, J. C., Bertol, I., Cassol, P. C., \& Amaral, A. J. D. (2005). Perdas de solo, água e nitrogênio por erosão hídrica em diferentes sistemas de manejo. Revista Brasileira de Ciência do Solo, 29(2), 277-286. https://doi.org/10.1590/S0100-06832005000200013

Hair, J. F., Anderson, R. E., Tatham, R. L., \& Black, W. C. (2005). Análise multivariada de dados (6th ed.). Bookman Editora.

Hickmann C., Costa L. M., Schaefer C. E. G. R., \& Fernandes, R. B. A. (2011). Morfologia e estabilidade de agregados superficiais de um Argissolo Vermelho-Amarelo sob diferentes manejos de longa duração e mata atlântica secundária. Revista Brasileira de Ciência do Solo, 35, 2191-2198.

Jones, J. B. (2001). Laboratory guide for conducting soil tests and plant analysis. Boca Raton, CRC Press LLC.

Kaiser, H. F. (1958). The varimax criterion for analytic rotation in factor analysis. Psychometrika, 23(3), 187-200. https://doi.org/10.1007/BF02289233

Kibblewhite, M. G., Ritz, K., \& Swift, M. J. (2008). Soil health in agricultural systems. Philosophical Transactions of the Royal Society of London B: Biological Sciences, 363(1492), 685-701. https://doi.org/ 10.1098/rstb.2007.2178

Lourente, E. R. P., Mercante, F. M., Alovisi, A. M. T.,Gomes, C. F., Gasparini, A. S., \& Nunes, C. M. (2011). Atributos Microbiológicos, Químicos e Físicos de Solo Sob Diferentes Sistemas de Manejo e Condições de Cerrado. Revista Pesquisa Agropecuária Tropical, 41(1), 20-28.

Lynch, D. H., Voroney, R. P., \& Warman, P. R. (2006). Use of $13 \mathrm{C}$ and $15 \mathrm{~N}$ natural abundance techniques to characterize carbon and nitrogen dynamics in composting and in compost-amended soils. Soil Biology and Biochemistry, 38(1), 103-114. https://doi.org/10.1016/j.soilbio.2005.04.022

Magalhães, A. G., Rolim, M. M., Duarte, A. D. S., Neto, E. B., Tabosa, J. N., \& Pedrosa, E. M. (2014). Desenvolvimento inicial do milho submetido à adubação com manipueira. Revista Brasileira de Engenharia Agricola e Ambiental, 18(7), 675-681. https://doi.org/10.1590/S1415-43662014000700001

Medina, J., Monreal, C., Barea, J. M., Arriagada, C., Borie, F., \& Cornejo, P. (2015). Crop residue stabilization and application to agricultural and degraded soils: A review. Waste management, 42, 41-54. https://doi.org/ 10.1016/j.wasman.2015.04.002 
Mélo, R. F., Ferreira, P. A., Ruiz, H. A., Matos, A. T., \& Oliveira, L. B. O. (2005). Alterações físicas e químicas em três solos tratados com água residuária de mandioca. Irriga, 10, 383-392.

Montanari, R., Carvalho, M. D. P., Andreotti, M., Dalchiavon, F. C., Lovera, L. H., \& Honorato, M. A. D. O. (2010). Aspectos da produtividade do feijão correlacionados com atributos físicos do solo sob elevado nível tecnológico de manejo. Revista Brasileira de Ciência do Solo, 1811-1822. https://doi.org/10.1590/ S0100-06832010000600005

Nasu, E. G. C., Pires, E., ermentini, H. N., \& Furlanetto, C. (2010). Efeito de manipueira sobre Meloidogyneincognita em ensaios in vitro e em tomateiros em casa de vegetação. Tropical PlantsPathology, 35(1), 32-36.

Neves, O. S. C., Souza, A. S., Costa, M. A., de Almeida Sousa, L., Viana, A. E. S., \& Neves, V. B. F. (2014). Persistência do cianeto e estabilização do $\mathrm{pH}$ em manipueira. Revista Brasileira de Tecnologia Agroindustrial, 8(1), 1274-1284. https://doi.org/10.3895/S1981-36862014000100012

Novais, R. F., Smyth, T. J., \& Nunes, F. N. (2007). Fósforo. In R. F. Novaes, V. V. H. Alvarez, N. F. Barros, R. L. F. Fontes, R. B. Cantarutti, \& J. C. L. Neves (Eds.), Fertilidade do solo. SBCS, Viçosa, MG.

Pavinato, P. S., \& Rosolem, C. A. (2008). Disponibilidade de nutrientes no solo: Decomposição e liberação de compostos orgânicos de resíduos vegetais. Revista Brasileira de Ciência do Solo, 32, 911-920. https://doi.org/10.1590/S0100-06832008000300001

Ponte, J. J. (2006). Cartilha da manipueira: Uso do composto como insumo agrícola (3rd ed.). Fortaleza: Banco do Nordeste do Brasil.

Portella, C. M. R., Guimarães, M. F., Feller, C., Fonseca, I. C. B., \& Tavares Filho, J. (2012). Agregação de solo com diferentes manejos. Revista Brasileira de Ciência do Solo, 36, 1868-1877. https://doi.org/10.1590/ S0100-06832012000600021

Ribeiro, A. T., Guimarães, P. T. G., \& Alvarez, V. H. (1999). Recomendação para o uso de corretivos e fertilizantes em Minas Gerais ( 5 a Aproximação). Viçosa: CFSEMG.

Rodrigues, A. P. D. A. C., Laura, V. A., Pereira, S. R., \& Deiss, C. (2012). Alelopatia de duas espécies de Braquiária em sementes de três espécies de estilosantes. Ciência Rural, 42(10), 1758-1753. https://doi.org/ 10.1590/S0103-84782012001000007

Salton, J. C., Mielniczuk, J., Bayer, C., Boeni, M., Conceição, P. C., Fabrício, A. C., ... Broch, D. L. (2008). Agregação e estabilidade de agregados do solo em sistemas agropecuários em Mato Grosso do Sul. Revista Brasileira de Ciência do Solo, 32(1), 11-21.

Santi, A. L., Amado, T. J. C., Cherubin, M. R., Martin, T. N., Pires, J. L., Della Flora, L. P., \& Basso, C. J. (2012) Análise de componentes principais de atributos químicos e físicos do solo limitantes à produtividade de grãos. Pesquisa Agropecuária Brasileira, 47(9), 1346-1357. https://doi.org/10.1590/S0100-204X201200 0900020

Santos, M. H. V., De Araújo, A. C., Dos Santos, D. M. R., Lima, N. Da S., De Lima, C. L. C., \& Santiago, D. A. (2010). Uso da manipueira como fonte de potássio na cultura da alface (Lactuca sativa L.) cultivada em casa-de-vegetação. Acta Scientiarum. Agronomy, 32(4), 729-733.

Sass, D. A., \& Schmitt, T. A. (2010). A comparative investigation of rotation criteria within exploratory factor analysis. Multivariate Behavioral Research, 45(1), 73-103. https://doi.org/10.1080/00273170903504810

Silva, F. C., Eira, P. A., Barreto, W. O., Pérez, D. V., \& Silva, C. A. (1998). Análises químicas para avaliação da fertilidade do solo: Métodos usados na Embrapa Solos. Rio de Janeiro, Embrapa/CNPS.

Souza Filho, A. P. S., Pereira, A. A. G., \& Bayma, J. C. (2005). Aleloquímico produzido pela gramínea forrageira Brachiaria humidicola. Planta Daninha, 23(1), 25-32. https://doi.org/10.1590/S0100-83582005000100004

Souza, D. M. G., Miranda, L. N., \& Oliveira, S. A. (2007). Acidez do solo e sua correção. In R. F. Novaes, V. Alvarez, V. H., Barros, N. F., Fontes, R. B. Cantarutti, \& J. C. L. Neves (Eds.), Fertilidade do solo. SBCS, Viçosa, MG.

Souza, S. O., Oliveira, L. C., Cavagis, A. D., \& Botero, W. G. (2014). Cyanogenic residues: Environmental impacts, complexation with humic substances, and possible application as biofertilizer. Water, Air, \& Soil Pollution, 225(12), 2223. https://doi.org/10.1007/s11270-014-2223-3

Statsoft, Inc. (2004). Statistica for Windows-Computer program manual. Tulsa. 
Stokes, G. G. (1851). On the effect of the internal friction of fluids on the motion of pendulums. Cambridge: Pitt Press.

Strudley, M. W., Green, T. R., \& Ascough Ii, J. C. (2008). Tillage effects on soil hydraulic properties in space and time: State of the science. Soil and Tillage Research, 99(1), 4-48. https://doi.org/10.1016/j.still. 2008.01.007

Tabachnick, B. G., \& Fidell, L. S. (2007). Using Multivariate Statistics (5th ed.). Boston: Allyn and Bacon.

Teixeira, P. C., Donagema, G. K., Fontana, A., \& Teixeira, W. G. (2017). Manual de métodos e analyses de solo (3rd ed). Revisada e Ampliada. Brasilia, DF: Embrapa Solos.

Tejada, M., \& Gonzalez, J. L. (2003). Effects of the application of a compost originating from crushed cotton gin residues on wheat yield under dryland conditions. European Journal of Agronomy, 19(2), 357-368. https://doi.org/10.1016/S1161-0301(02)00089-8

Vezzani, F. M., \& Mielniczuk, J. (2011). O solo como sistema (edição dos autores). Curitiba.

Widaman, K. F. (2007). Common factor versus components: Principals and principles, errors and misconceptions. In R. Cudeck, \& R. C. Mac-Callum (Eds.), Factor Analysis at 100: Historical Developments and Future Directions. London: Lawrence Erlbaum Associates.

Yoder, R. E. (1936). A direct method of aggregate analysis of soils and a study of the physical nature of erosion losses. Journal of the American Society of Agronomy, 28(5), 337-351. https://doi.org/10.2134/agronj1936. $00021962002800050001 \mathrm{x}$

\section{Copyrights}

Copyright for this article is retained by the author(s), with first publication rights granted to the journal.

This is an open-access article distributed under the terms and conditions of the Creative Commons Attribution license (http://creativecommons.org/licenses/by/4.0/). 